\title{
Mitigation Schemes for Banggae Future Tsunami, West Sulawesi Province, Indonesia
}

\author{
Achmad Yasir Baeda $^{\mathrm{a}, *}$, Nurhidayani Namiruddin ${ }^{\mathrm{b}}$ \\ ${ }^{a}$ Marine Disaster and Weather Anomalies Laboratory, Department of Ocean engineering, Universitas Hasanuddin, Makassar, Indonesia. \\ E-mail: baeda@eng.unhas.ac.id \\ ${ }^{\mathrm{b}}$ Department of Ocean Engineering, Universitas Hasanuddin, Makassar, Indonesia.
}

\begin{abstract}
Geologically, Sulawesi Island is a complex area. It is caused by the convergence between three lithosphere plates, where the Australian Plate drifting to North, Pacific to West, and Eurasia from South to South-East respective. The future tsunami simulation was done by using SiTProS (Siam Tsunami Propagation Simulator) Version 1.5., which uses data such as earthquakes coordinate, magnitudes, focus depths, and propagation scheme, as the main input parameters in the simulations. Based on those future tsunami simulations results, the mitigation scheme chosen for Banggae District of Majene Region, West Sulawesi Province is the Vertical Tsunami Mitigation scheme. Due to its detailed parameters i.e. population details, evacuation time, distance and speed, the Vertical Tsunami Mitigation Scheme can determine the existence of shelters parameters and analyze the additional shelters needed in precise manner.
\end{abstract}

Keywords: Banggae; mitigation; sulawesi; tsunami

\section{Introduction}

Sulawesi Island has a development for tectonic activities since tertiary era. Due to this development, Sulawesi is included as one of active place in Indonesia which has geologically complex phenomenon. The tectonic manifestation formed fault and volcano in Sulawesi, such us; Walanae Fault in South Sulawesi, Palu Koro Fault expanded from Flores to Makassar Strait, Gorontalo Fault, Batui Fault in Central Sulawesi, Matano Fault, and Kolaka Fault (Southeast Sulawesi). The intersection areas of fault should be watched out and get more attention because these are the areas which generate earthquake causing geological problem.

Based on the historical data, it can be said that the earthquake and tsunami that happened in Majene in 1969 with 6.9 magnitude was caused by the movement of Saddang Fault and several small tectonic activities in South Sulawesi Province at that time. The movement of sea floor spreading

*Corresponding author. Mobile:+62-851-4500-7300

Faculty of Engineering, UNHAS

Jl. Poros Marino, Bontomarannu, Gowa, South Sulawesi 92171 in Makassar Strait that moved from West to East, can cause pressure impact to the region near by the Saddang Fault. Moreover, the activity of Saddang Fault is also caused by the movement of small plates such as Tempe Lake and Sidenreng (East side of Saddang Fault) which are moving from North-West to East respectively. Besides, the movement of sea floor spreading from East to West at Bone Bay was also actively contributed to tsunamigenicearthquake event in 1969. The development of this mitigation schemes was based on future tsunami modelling for Banggae Beach, West Sulawesi Province.

Tsunami is a series of ocean waves typically caused by undersea earthquakes or volcano eruptions at tectonic plate boundaries. The surges of water may reach 100 feet and cause widespread destruction when they crash ashore. They race across the sea at a speed up to 500 miles per hour and cross the entire Pacific Ocean in less than a day. Their long wavelength means that they lose very little energy along the way. 


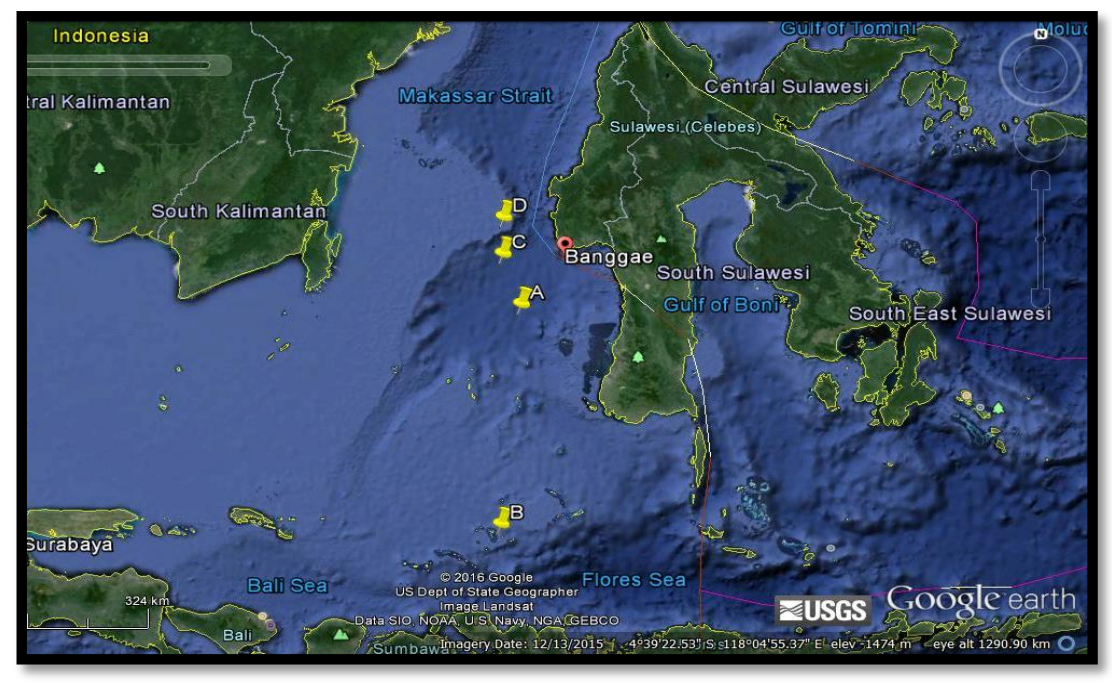

Figure 1. Territory restriction for tsunami simulation in Banggae (from Google Earth)

\section{Research Methods}

The data collected in this research are underwater earthquake direct observation in Banggae Beach, Majene Regency West Sulawesi. The underwater earthquake data were collected from Global Moment Tensor (Global CMT) and USGS which are has $>5$ magnitude. The territory restriction for this research was done in google earth as seen in figure 1, those data will be simulated in SiTProS version 1.5.

The results of this propagation modeling become the input of the preparation for developing a suitable mitigation schemes conducted by direct observation at Banggae Beach, Majene Regency, West Sulawesi Province.

\section{Analysis and Discussion}

Majene is a coastal city bordered by the Mandar bay and the strait of Makassar to the west, and it comfortably nestled in a semicircular valley against a backdrop of rolling, forested hills. The city covers a total area 55.19 square kilometers. Majene Regency consists of 8 districts; Banggae, West Banggae, Pamboang, Sendana, Rangas, Tubo Sendana, Malunda, and Ulumanda. The capital of Majene Regency is located in Banggae District. Geographically, Majene is located in $2^{\prime} 38^{\prime} 45^{\prime \prime} \mathrm{N}-3^{\prime} 38^{\prime} 15^{\prime \prime} \mathrm{N}$ and $118^{\prime} 45^{\prime} 00^{\prime \prime} \mathrm{E}-$ 119'4'45''E.

In 1969, an earthquake occurred in Majene and caused 64 people died, 97 people injured, and 1287 residences and public areas were damaged and destroyed. The pier broke along 50 meters and it raised 4 meters tsunami wave in Palatoang and 1.5 meters in Parasanga and Palili.

The tsunami was caused by the activity of Saddang Fault influencing another seismic activities in South Sulawesi.
Due to the historical tsunami accident, the government in Banggae has already prepared for future tsunami. They already put and point out several places as the evacuation areas. Generally, most of every districts in Banggae can reach the evacuation areas except Rangas district.

Modeling of tsunami propagation is done by Siam Tsunami Propagation Simulator (SiTProS) Version 1.5 which is based on a regional or global network with bathymetric and topographic dataset of ETOPO2. The basic term of determining the source of the tsunami in the form of underwater earthquakes are based on Sulawesi's Seismic Systems of faults that can generate tsunami $[1,2]$

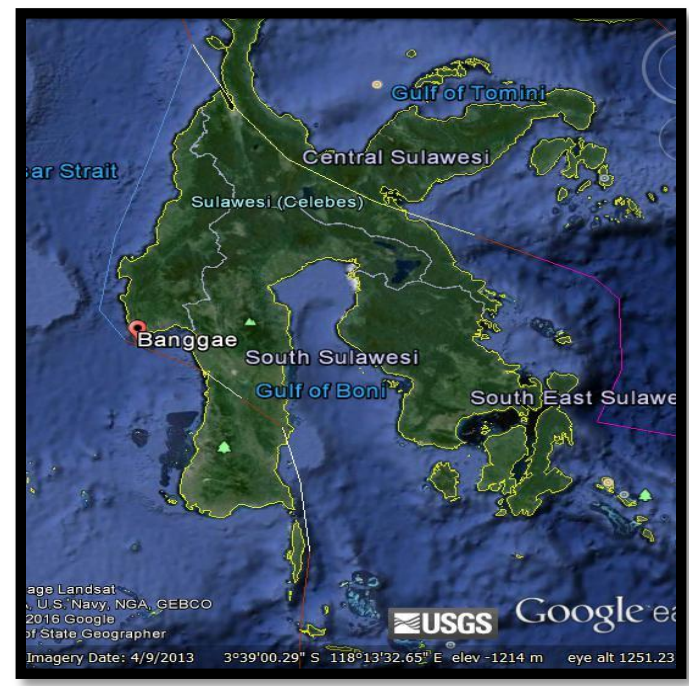

Figure 2. The city of Banggae (from Google Earth) 

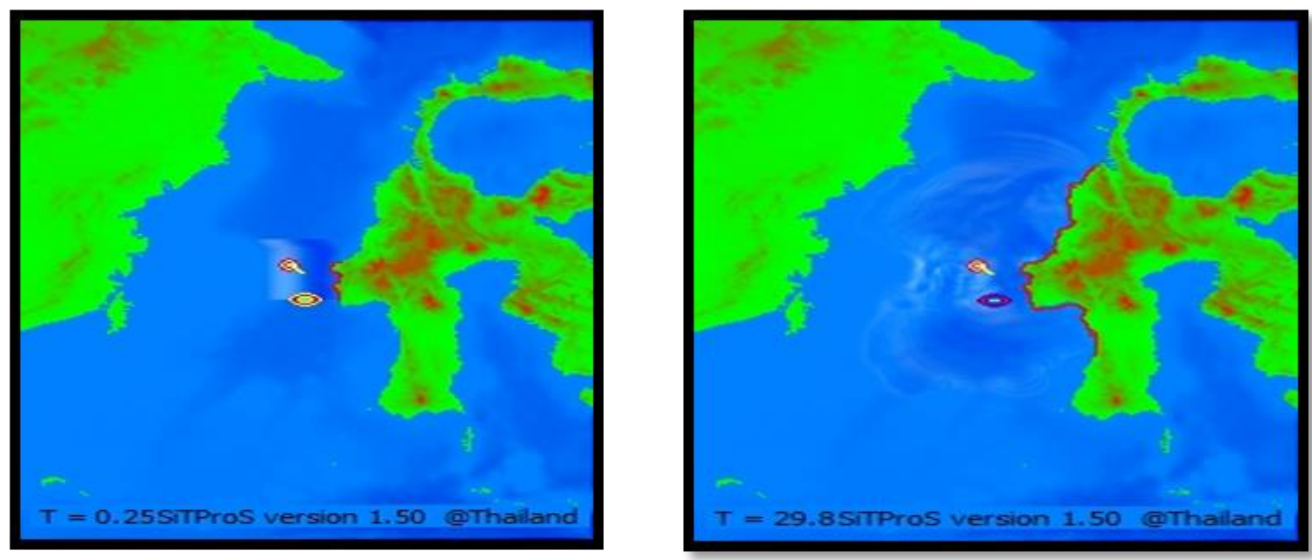

Figure 3. Tsunami Simulation in Banggae Beach with magnitude 6.9, Majene Regency, West Sulawesi Province
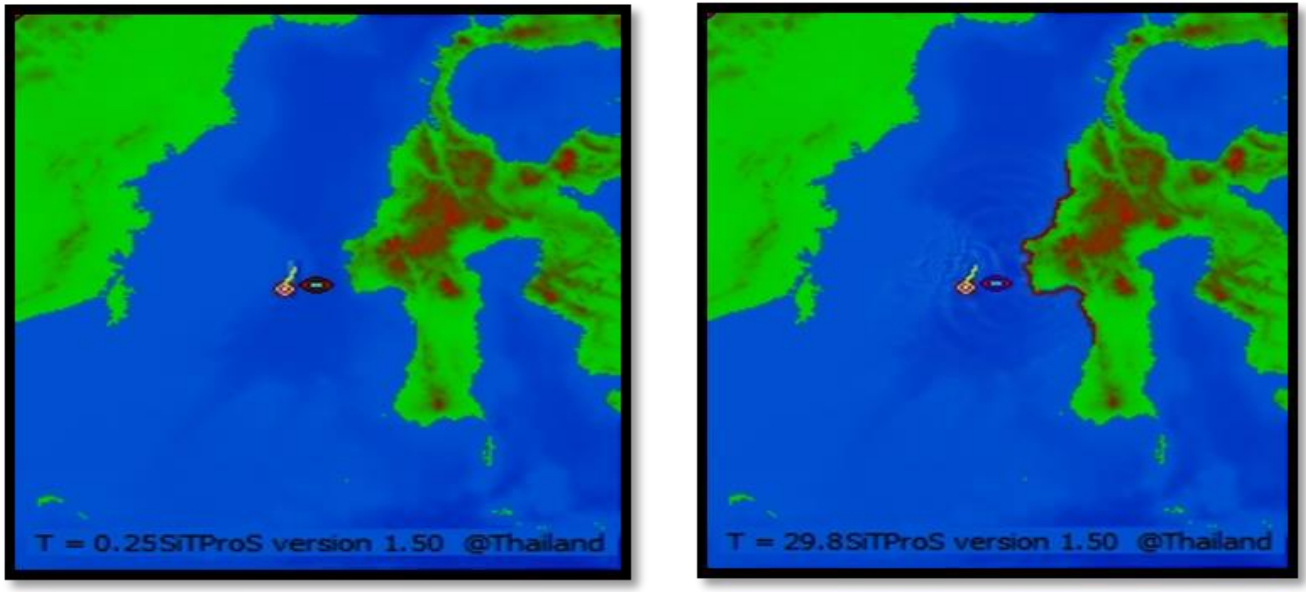

Figure 4. Tsunami Simulation in Banggae Beach with magnitude 5.8, Majene Regency, West Sulawesi Province

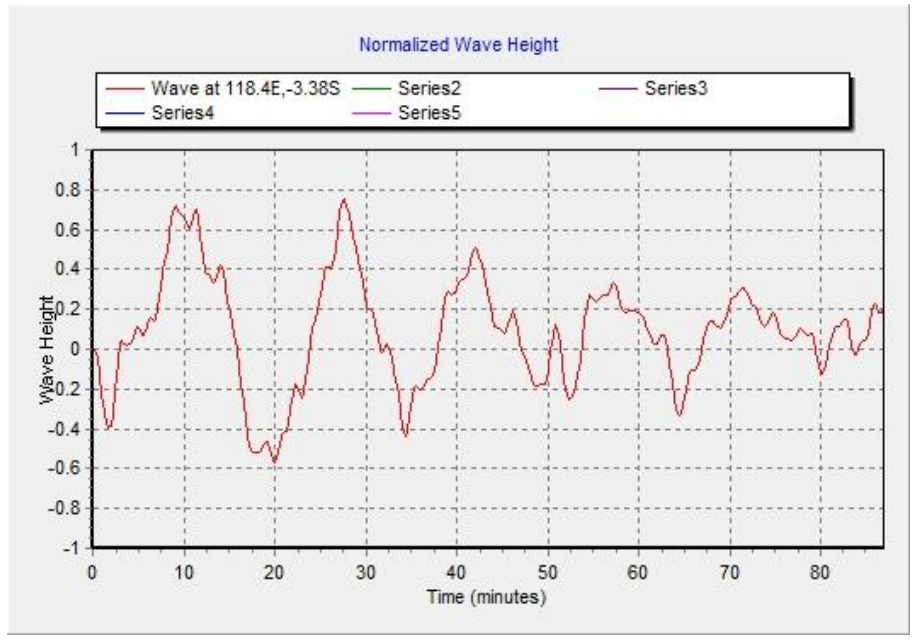

Figure 5. A 6.9 Magnitude Banggae tsunami (normalized) and its time series in minutes 


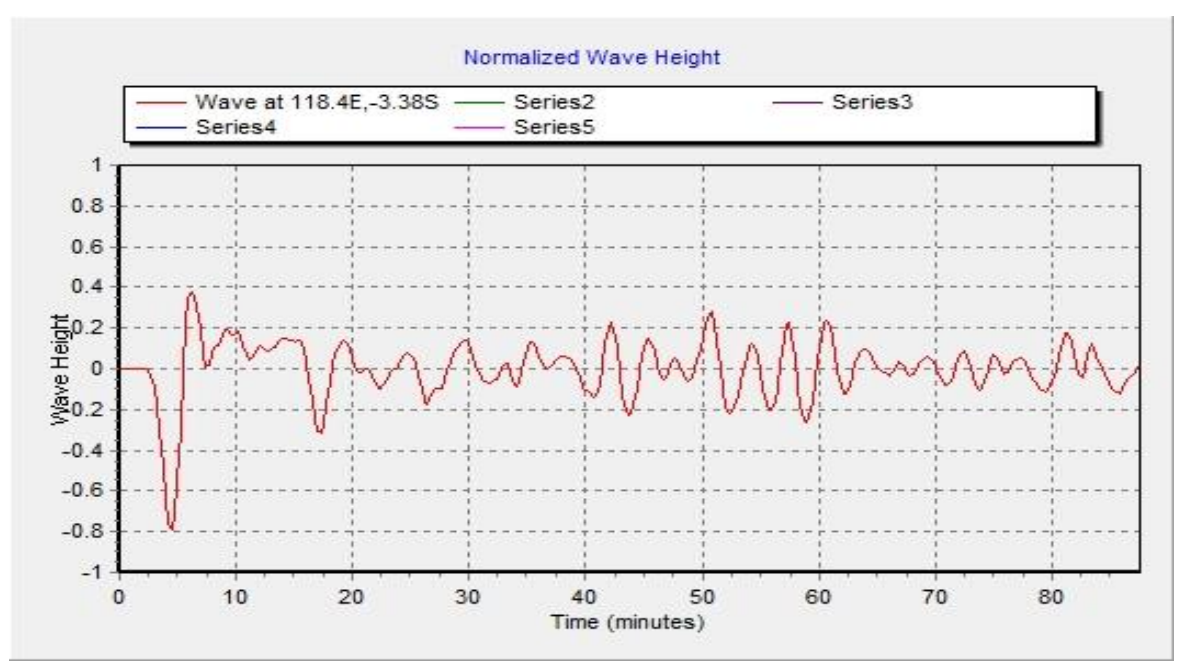

Figure 6. A 5.8 Magnitude Banggae tsunami (normalized) and its time series in minutes

Tsunami Simulation

The tsunami is generated by using underwater earthquake data in Makassar Strait which is taken from USGS and Global CMT. The epicenter of underwater earthquake is located in $118.72 \mathrm{E}$ and $-2.77 \mathrm{~S}$ depth $14.8 \mathrm{~km}$ with magnitude 6.9 and $118.12 \mathrm{E}$ and $-3.44 \mathrm{~S}$ depth 18.8 with magnitude 5.8.

Based on the simulation, tsunami reaches shore at 9 minutes with magnitude 6.9 after the main shock. The highwave of tsunami can be seen in Fig.5.

Based on simulation result, it can be seen that the fluctuation happened at minute 3 (initial drawndown), and the arrival tsunami waves to shore at minute 9 (run-up). It is obviously seen that the fluctuation of tsunami waves happens repeatedly until minute 70 . By using the Aydan's formula [3], it found out that the earthquake in epicenter of $-2.77 \mathrm{~S}$ and $118.72 \mathrm{E}$ has a moment magnitude $(\mathrm{Mw})=6.7$, so;

$$
\begin{aligned}
& \mathrm{Hm}=\mathrm{A} \times \mathrm{Mw} \exp (\mathrm{b} \times \mathrm{Mw}) \\
& \mathrm{Hm}=0.004 \times 6.7 \exp (0.9 \times 6.7) \\
& \mathrm{Hm}=11.14 \mathrm{~m}
\end{aligned}
$$

Because the maximum wave height is $70 \%$ of the tsunami height, so;

$$
\mathrm{Hm}=11.4 \times 0.7=7.80 \mathrm{~m}
$$

For the height of tsunami run-up:

$$
\begin{aligned}
& \Delta \mathrm{Hr}=\mathrm{B} \times \mathrm{Hm} \\
& \Delta \mathrm{Hr}=2.5 \times 7.80 \\
& \Delta \mathrm{Hr}=19.50 \\
& \mathrm{Hr}=\mathrm{Hm}+\Delta \mathrm{Hr} \\
& \mathrm{Hr}=7.80+19.50 \\
& \mathrm{Hr}=27.30 \mathrm{~m}
\end{aligned}
$$

The height of tsunami in buoy is $7.80 \mathrm{~m}$ with run-up 27.30. It is shows that the society in Banggae Beach only needs 9 minutes for evacuated.
In Fig. 6, we can see the arrival time for tsunami to shore at 6 minutes with magnitude 5.8 after the main shock. Based on simulation result, it can be seen that the fluctuation happened at minute 5 (initial drawndown), and arrival time for tsunami waves in shore at minute 6 (run-up). This indicates that the maximum wave crashing on the beach occurred at the first wave. By using the Aydan's formula (2008), it can be found out that the earthquake in epicenter of $118.12 \mathrm{E}$ and $-3.44 \mathrm{~S}$ has a moment magnitude $(\mathrm{Mw})=5.8$ SR, so;

$$
\begin{aligned}
& \mathrm{Hm}=\mathrm{A} \times \mathrm{Mw} \exp (\mathrm{b} \times \mathrm{Mw}) \\
& \mathrm{Hm}=0.004 \times 5.8 \exp (0.9 \times 5.8) \\
& \mathrm{Hm}=4.29 \mathrm{~m}
\end{aligned}
$$

Because the maximum wave height is $40 \%$ of the tsunami height, so;

$$
\mathrm{Hm}=4.29 \times 0.4=1.72 \mathrm{~m}
$$

For the height of tsunami run-up:

$$
\begin{aligned}
\Delta \mathrm{Hr} & =\mathrm{B} \times \mathrm{Hm} \\
\Delta \mathrm{Hr} & =2.5 \times 1.72 \\
\Delta \mathrm{Hr} & =4.29 \\
\mathrm{Hr} & =\mathrm{Hm}+\Delta \mathrm{Hr} \\
\mathrm{Hr} & =1.72+4.29=6.01 \mathrm{~m}
\end{aligned}
$$

The height of tsunami in buoy is $1.72 \mathrm{~m}$ with run-up 6.01 . All the simulation shows that the short evacuating time is 6 minutes and the highest run up is $27.30 \mathrm{~m}$.

\section{Tsunami Evacuation Time}

According to simulation result by using SiTProS, this research found estimated time that can be used for evacuating. This evacuation time consist of early warning, preparation time, and evacuation time itself. This research takes the short time arrival tsunami waves to shore at 6 minute. The evacuation time analysis can be seen in Fig. 6 . 


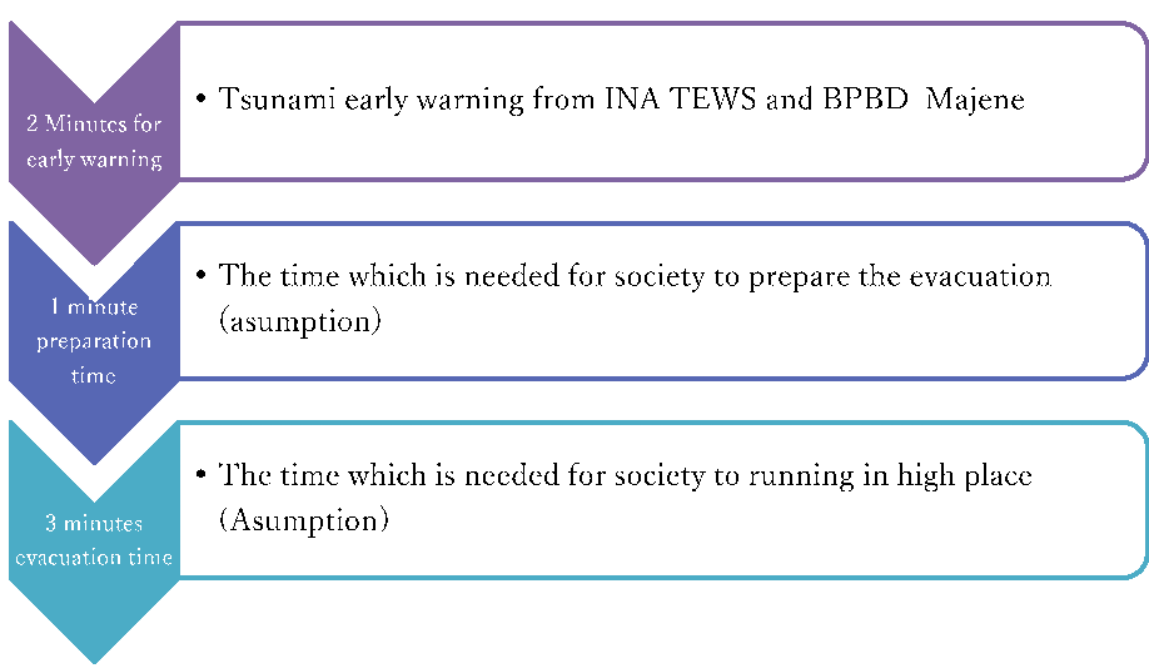

Figure 7. Tsunami Evacuation Time in Banggae Beach, Majene Regency, West Sulawesi Province
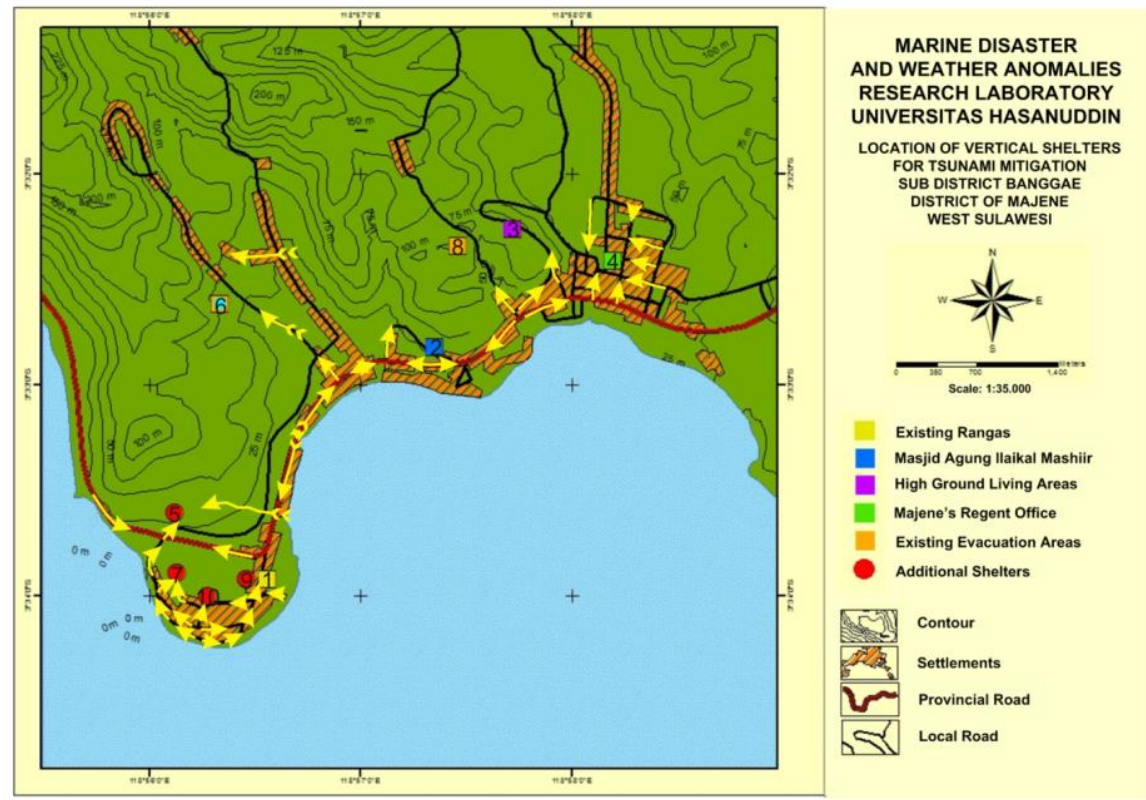

Figure 8. Shelters location for Banggae, Majene Regency, West Sulawesi Province

EvacuationWalking Speed and Evacuation Distances

The evacuation walking speed applied is based on The Japan Institute for Fire Safety and Disaster Preparedness. The pace for Banggae beach is $0.751 \mathrm{~m} / \mathrm{s}$ or $45.06 \mathrm{~m} /$ minutes. Because evacuation time is 3 minutes and evacuation walking speed is 45.06 , so the evacuation distance is about 135 meters. Therefore the shelter location in Banggae beach should be around 135 meters. However, as seen the topographic and measured by the society walking speed, the shelter can be put around 300-500 meter.
Shelter capacity analysis

The temporary space requirements is $0.5 \mathrm{~m}^{2}$ per person, so that two people can be placed in $1 \mathrm{~m}^{2}$. In condition that the refugees will sit without chair for several hours. This sit position will take $0.42 \mathrm{~m}^{2}$ until $0.55 \mathrm{~m}^{2}$ per person [4].

Especially in Rangas district, the number of population is 7300 , so that the space requirements that is needed $0.55 \mathrm{~m}^{2}$ $\mathrm{x} 7300=4015 \mathrm{~m}^{2}$. 
$\underline{\text { Shelters Location }}$

There will be 10 shelters location in Banggae, those shelters consist of 6 existing shelters and 4 additional shelters. All the additional shelters will be built in Rangas district. For society around Rangas the shelters location are shown in 1,5,7,9 and 10. While For society around Jl. Tenne Heiko, Jl. Kartini, Jl. Gatot Subroto the shelters location are shown in 2, 3, and 4. For society around Sandeq Monument Boat the shelter location is shown in 8. And for society around Jl. Ahmad Yani the shelter location is shown in 6 . All of these shelters are located in crowded population so that society can be evacuated themselves when tsunami happens.

\section{Conclusions}

The tsunami mitigation in Banggae is focused for shelters location that it can be reached by local society when tsunami occur. In order to maximize the shelters location and reduce the number of victim and broken infrastructure during tsunami, they have to be well-managed due to the time arrival for tsunami to shore only 6 minutes. The shelters location and awareness about tsunami also should be socialized to the society. The evacuation can be done by fast walk, run, and by using motorcycle.

\section{References}

[1] Baeda, A.Y., et al., Tsunami Mitigation Plan for Manakarra Beach of West Sulawesi Province, Indonesia, 8th International Conference on Asia and Pasific Coast (APAC 2015), Procedia Engineering Vol. 116: 134-140, 2015.

[2] Baeda, A.Y., et al., Mitigation plan for future tsunami of Seruni Beach Bantaeng, 2nd International Seminar on Ocean and Coastal Engineering, Environment and Natural Disaster Management, ISOCEEN 2014, Procedia Earth and Planetary Science, ELSEVIER, Vol. 14 (2015): 179-185, 2015

[3] Aydan O., Seismic and Tsunami Hazard Potential in Indonesia with a special emphasis on Sumatra Island, Journal of The School of Marine Science and Technology, Tokai University, Vol. 6 No. 3. pp 19-38, 2008 ,

[4] Neufert, E., 1980, Architects' Data, Blackwell Science Ltd. London. 